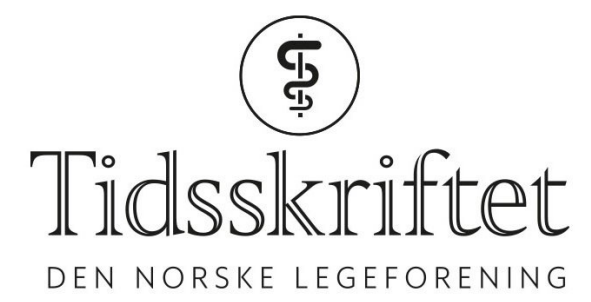

\title{
Etiske dilemmaer ved suicidalitet
}

KOMMENTAR

OLAV MAGNUS FREDHEIM

E-post: olav.m.fredheim@ntnu.no

Olav Magnus Fredheim er overlege og professor.

MORTEN MAGELSSEN

Forfatterne har ikke oppgitt noen interessekonflikter.

Vi takker $\emptyset$. Ekeberg for hans kommentar (1) til vår artikkel om etiske dilemmaer ved suicidalitet hos pasienter med kort forventet levetid (2). Imidlertid mangler det noe grunnleggende i Ekebergs innlegg, nemlig en anerkjennelse av at spørsmålet om tvangstiltak er et etisk dilemma, en verdikonflikt. Ekeberg må gjerne vekte de etiske momentene annerledes enn vi gjør, men i innlegget hans er det ingen spor av innsikten om at velmente tvangstiltak kan påføre skade. Som vi redegjør for i vår artikkel, vil tvang gå imot pasientens selvbestemmelse og potensielt kunne medføre integritetskrenkelse, overbehandling og forlengelse av en plagsom dødsprosess. I tillegg kan en tvungen innleggelse i psykisk helsevern frarøve pasienten den spesialiserte palliative behandlingen som vil være nødvendig for å lette symptomtrykket. Dette er både et praktisk og et etisk argument.

Når Ekeberg argumenterer for tvangstiltak for pasienten i vår kasuistikk 1, er det naturligvis et legitimt etisk standpunkt. Vi hadde gjerne sett at han utdypet hvorfor han mener det er det beste handlingsalternativet i dette etiske dilemmaet. Imidlertid er det viktig å gjøre oppmerksom på at tvangstiltakene som Ekeberg - i motsetning til oss - mener at er den beste løsningen, ikke har noen hjemmel i relevant lovverk. Tvangsinnleggelse i psykisk helsevern krever at pasienten både oppfyller kriteriet om fare og hovedkriteriet om alvorlig sinnslidelse. Kriteriet om alvorlig sinnslidelse vil her ikke være oppfylt.

Når det gjelder kasuistikk 2, argumenterer vi i artikkelen for at livreddende tiltak skal startes hos den ikke-samtykkekompetente pasienten. Her er altså vi og Ekeberg enige. Vurderingen av hvor omfattende, langvarige og plagsomme tiltak som skal settes i verk, bør imidlertid ta hensyn til pasientens forventede levetid og symptomtrykk den gjenværende levetiden. Behandlingen må være motivert av utsikter til å skaffe pasienten gode dager.

Vi antar at Ekebergs påstand om at pasienter som har behov for opioidreseptorantagonister, ikke kan være samtykkekompetente, skyldes en misforståelse. Samtykkekompetanse avgjøres jo ikke av hvilke medikamenter pasienten får, men av den kognitive funksjonen i seg selv. En pasient som har inntatt høye doser med langtidsvirkende opioider eller opioider i depotformulering, kan være avhengig av langvarig infusjon av opioidreseptorantagonist for å unngå respirasjonsdepresjon. Dersom pasienten med slik pågående infusjon er våken, klar og orientert, mener vi at det både er etisk og juridisk er 
galt å frata denne pasienten retten til å avslutte livsforlengende behandling.

Avslutningsvis er det verd å nevne at vi er uenige med Ekeberg i at det er et motsetningsforhold mellom å ha vilje til å «forebygge selvmord» i denne pasientgruppen gjennom god og helhetlig palliativ behandling, og det å legge vekt på pasientens autonomi når det etiske dilemmaet settes på spissen.

\section{LITTERATUR:}

1. Ekeberg Ø. Selvmordsatferd blant alvorlig syke pasienter. Tidsskr Nor Legeforen 2019; 139. doi: 10.4045/tidsskr.19.0542. [PubMed][CrossRef]

2. Fredheim OMS, Magelssen M. Etiske dilemmaer ved suicidalitet hos pasienter med kort forventet levetid. Tidsskr Nor Legeforen 2019; 139. doi:10.4045/tidsskr.19.0157. [PubMed][CrossRef]

Publisert: 13. januar 2020. Tidsskr Nor Legeforen. DOI: 10.4045/tidsskr.19.0797

(C) Tidsskrift for Den norske legeforening 2020. Lastet ned fra tidsskriftet.no 